\title{
THE POLITICAL ECONOMY OF MORAL HAZARD
}

\author{
Jörg Guido HÜLSMANN, Université d'Angers
}

\section{Introduction}

A central occupation of economists is to analyse the nature, causes, and effects of incentives - the circumstances that are held to motivate human action. Economists agree on the positive role that certain incentives can play in inducing efforts to increase production. They also agree that other incentives have a rather negative impact on productive activity. One of these perverse incentives is called moral hazard, the subject of our present essay.

Moral hazard is present in "actions of economic agents [...] to the detriment of others in situations where they do not bear the full consequences [...] of their actions." "1) It is the incentive of a person A to use more resources than he otherwise would have used, because he knows, or believes to know, that someone else B will provide some or all of these resources. The important point is that this occurs against B's will and that B is unable to sanction this expropriation immediately. The mere incentive to rely on resources provided by others is not per se problematic. For example, the announcement of a future inheritance might prompt the prospective heir to spend more in the present than he would otherwise have spent. In such cases we would not speak of moral hazard. A genuine moral-hazard problem appears however if A has the possibility to use B's resources against B's will and if he knows this. Laymen would call A's incentives a "temptation to steal" or a "temptation to act irresponsibly." Economists, ever weary of moralising, have espoused the technocratic expression "moral hazard." 2

Thus the essential feature of moral hazard is that it incites some people A to expropriate other people B. ${ }^{3)}$ The B-people in turn, if they realise the presence of such a moral hazard, have an incentive to react against this possible expropriation. They make other choices than those that they would consider to be best if there were no moral hazard. Many economists have concluded therefore that moral hazard entails market failures; it brings about a different allocation of resources than the one that would exist in the absence of moral hazard. Thus the economy deviates from its optimum path and possibly generates disequilibria. The possible mechanisms of this process have been studied in a great variety of circumstances.

*) The author is a professor of economics at the Université d'Angers and a senior fellow of the Mises Institute. He would like to thank Nathalie Janson, Bertrand Lemennicier, Laurent Carnis, Antoine Gentier, Nikolay Gertchev, Arnaud Pellissier-Tanon, and Marian Eabrasu for comments on a previous version of this paper

1) See Kotowitz (1987, p. 549). The author explains that moral hazard may be "due to uncertainty and incomplete or restricted contracts which prevent the assignment of full damages (benefits) to the agent responsible." See also McTaggart, Findlay and Parkin (1992); Katz and Rosen (1994).

2) The expression has been introduced into economic analysis by Frank Knight (1921) and Kenneth Arrow (1963), but the phenomenon has of course been known since the times of Adam Smith. See Laffont and Martimort (2002).

3) The expression "expropriation" of B is a short synonym for the more long-winding "using B's property against his will with impunity." We use it as a technical term following Rothbard (1998) and Hoppe (1993). 
And various remedies have been proposed to prevent moral hazard from causing market failures, usually involving some form of government intervention.

Now, whatever the remedy might be, it must be based on a pertinent diagnosis of the causes of moral hazard. The conventional theory of the causes of moral hazard has emerged in the 1970s based on the paradigmatic works of Arrow (1963), Mirrlees (1971, 1976), and Holmstrom (1979). It explains moral hazard as a consequence of the fact that market participants are unequally well informed about economic reality. In other words, moral hazard results from "asymmetries of information" and the theory of moral hazard is therefore considered to be a part of the economics of information.

In the present paper we will propose an alternative approach. We will argue that information asymmetries are just one among several causes of moral hazard. They entail disequilibria and the expropriation of third parties only accidentally and ephemerally, because these third parties can avoid them by anticipation. ${ }^{4}$ By contrast, moral hazard also results from government interventionism; and in this case it creates disequilibria and expropriation of a sort that cannot be avoided. Most importantly, in this case disequilibria and expropriation do result even in the absence of informational asymmetries.

It follows that the political economy of moral hazard, rightly conceived, is not a part of information economics, but of property economics - the discipline that analyses how the acquisition of property determines human behaviour.

We will first present the conventional "informational" theory of the causes and consequences of moral hazard. Then we will study moral hazard on the free market and under government interventionism. Finally we will outline how our findings fit the important case of government interventionism in money and financial markets.

\section{The Conventional Theory of Moral Hazard}

The fact that people act on the basis of different knowledge about the real world will hardly be contested. The baker knows other things than the astronaut, the opera singer other things than the teacher of mathematics. Neither can it be doubted that people are unequally well informed about the real world. Some bakers know more about cakes, cake making, and the cake market than others, and so on. In short, information asymmetries are a universal aspect of human life as we know it. They are both a cause and a result of the division of labour. There is no reason to suppose that they are a priori harmful or a sign of imperfection.

Information asymmetries do not all by themselves entail the disposition that we call moral hazard. They do not per se give to some men the possibility to use the resources of other men against the latter's will. In particular, they do not per se incite human beings to behave irresponsibly. A baker who knows less than his fellow-baker does not therefore adopt a more risky business strategy. He might in fact adopt a more risky strategy or a less risky strategy; yet we have no reasons to assume that he would do the one or the other because of asymmetries of information. It is therefore that the conventional theory stresses an additional condition to explain the emergence of moral hazard, namely, the separation of ownership and

4) The notion that moral hazard entails market failures has also been criticised from the point of view of contract theory. The idea is that suitably designed contracts could neutralise moral hazard's unwelcome effects. See for example Laffont and Martimort (2002). 
control. ${ }^{5}$ Two main cases can be distinguished: co-ownership and agency contracts.

In the case of co-ownership, any one owner has control over a given piece of property, but not exclusive control. Informational asymmetries can then produce moral hazard in conjunction with this separation of ownership and control. Whenever one co-owner of a swimming pool cannot effectively monitor the activities of his fellow-owners, the latter have an incentive to swim without cleaning up, repairing the fences and so on, thus increasing their own (monetary and psychic) income at his expense.

Similarly, in the case of an agency contract, moral hazard can arise when an economic good is not effectively controlled by its owner (the "principal") but by a different person called the "agent," for example, by an employee. Again, informational asymmetries produce moral hazard in conjunction with this separation of ownership and control. The agent, who is fully informed about his own activities, has an incentive to act in his own material interest against the material interests of his less informed principal. Whenever the principal cannot effectively monitor the activities of his agent, therefore, the latter has an incentive to increase his own (monetary and psychic) income at the expense of the former.

The standard case of moral hazard in an agency setting is an insurance contract. Here the insurance is the less informed principal and the insured person is the agent. Automobile insurance for example creates a moral hazard for drivers; it creates an additional incentive for risky driving because other people (other clients of the insurance) will pay a part of the costs of the accidents. Similarly, in the presence of unemployment insurance, an unemployed person has an additional incentive to stay unemployed because other people will pay at least a part of his living expenses (see Spycher, 2000). Or, in the presence of health insurance, insured people will have an additional incentive to engage in risky activities or life styles because others will pay at least a part of the treatment in case of illness or accidents (see Mises, 1922).

However, moral hazard is in no way a particular problem of the insurance industry. ${ }^{6}$ It can arise in almost any other field of human activity where there is a separation of ownership and control. Employees can be subject to moral hazard to the extent that can reduce their efforts without fearing reduced pay. Debtors may be subject to moral hazard if they believe they can squander the money without negative consequences when they turn out to be incapable of paying back. Certain auditing firms have been subject to moral hazard when they sold consulting services to the very companies they were supposed to audit (for example, in the Enron case). A central bank can produce moral hazard in the banking community if the commercial bankers perceive the central bank as a lender of last resort. The IMF can produce moral hazard among debtor governments (see Dreher, 2004). Taxpayers are said to be subject to moral hazard if they can evade high-tax regions, and so on. Similarly, in the literature on public choice and constitutional political economy, go-

5) See in particular Mirrlees (1971, 1976); Holmstrom (1979); Grossman and Hart (1983). For early paradigmatic works on the separation of ownership and control see Hilferding (1910), Keynes (1926), and Berle and Means (1932). According to Arrow (1985), the separation of ownership and control creates two types of information asymmetries: hidden knowledge (which entails adverse selection) and hidden action (which entails moral hazard).

6) Arguably, even in the case of insurance, the moral hazard problem is not as formidable as it appears. To some extent, at least, insurance is not a direct substitute for self-protection or self-insurance, but rather a complement. See Becker and Ehrlich (1972) and Rotschild and Stiglitz (1976). I am indebted to Prof. Lemennicier for this reference. 
vernments and parliaments are often portrayed as agents prone to moral hazard, whereas the voters are the less informed principals (see Laffont, 2002).

As the variety of these examples shows, moral hazard is a rather pervasive phenomenon. For this reason alone, it merits careful study and it has in fact been studied repeatedly and attentively - though not always under the name "moral hazard" - in the history of our science. ${ }^{7)}$

It is a rather significant fact that, in the light of the conventional theory, information asymmetries produce moral hazard only in conjunction with the separation of ownership and control. We will argue that the latter is indeed the decisive element, whereas information asymmetries are but a sideshow. More to the point, we will argue that moral hazard systematically entails expropriation only when ownership and control of a resource are separated in a special way, namely, without the consent of the owner. To demonstrate our contention, we will first analyse the voluntary separation of ownership and control, as it occurs on a free market and then turn to the most important case of involuntary separation, namely, the case of interventionism.

\section{Moral Hazard on the Free Market}

When we speak of a free market, we mean that each property owner has the unhampered right to use his property as he sees fit (see Rothbard, 1998). This includes the right to let other people use his property under conditions he approves, as well as the right to co-own property with other people. In short, it includes purely voluntary separations of ownership and control.

The question we have to answer now is whether such a voluntary separation of ownership and control is per se likely to lead to any sort of expropriation due to information asymmetries. In other words, we have to examine whether the conjunction of these two conditions is sufficient for one man to enrich himself at the expense of another man, or whether, to the contrary, even in the presence of the combined two conditions, such expropriation of man by man is a contingent consequence. We will argue that moral hazard does not necessarily entail expropriation whenever information asymmetries combine with a separation of ownership and control; that, whenever moral hazard results from them accidentally, there are strong forces at work to eliminate expropriation; and that moral-hazard-induced expropriation is therefore not only accidental, but also ephemeral on the free market.

The decisive fact on which we can base our argument is that the interplay between information asymmetries on the one hand, and the separation of ownership and control on the other hand, finds on the free market an effective antidote in expectations. Consider the problem of principal-agent relationships. Suppose the owner of a grocery shop hires a clerk for a salary of $€ 1.000$ per month. Suppose further that that the owner has various other shops to run and that he can therefore not effectively supervise his new clerk all the time. According to the conventional theory, the clerk is likely to behave differently than he would in the permanent presence of his employer. He can have longer naps over the lunch break, be sloppier in dealing with customers, and so on. All of this, we can admit right away. But the crucial question is: does the sloppy clerk necessarily enrich himself at the expense

7) We cannot at this place review this history. We notice however that earlier approaches stressed the influence of property regimes on moral hazard (see in particular Mises' analyses of socialism, interventionism, and fractional-reserve banking in the 1920s). Only in the 1960s and 1970s did economists start to reinterpret moral hazard from the point of view of the burgeoning discipline of information economics. This discipline relied at least in part on Hayek's paradigmatic work on the use of knowledge in society (1945). 
of his employer? Does the principal necessarily bear costs entailed by the unfaithful agent? Only if this were the case could we speak of systematic expropriation and market failure. But it is not the case. The clerk does not necessarily enrich himself at the expense of the owner because the latter can anticipate the behaviour of the former. To the extent that he does anticipate it, the payment of $€ 1.000$ would properly reflect the discounted marginal value product of sloppy labour. And this is of course precisely what prudent employers do, on a free market, whenever they hire new people. They discount the marginal value product of good or normal work by a factor that represents the risk of bad work due to lack of supervision.

The role of expectations can hardly be overstated in the theory of moral hazard. To the extent that the expectations of the principal are correct, moral hazard on the part of the agent cannot lead to a situation in which the latter expropriates the former. ${ }^{8)}$

Moreover, principals acting on a free market do not merely have to rely on their foresight of the future actions of their agents. They are also free to design contractual relationships in ways that minimise: a) the danger of moral hazard arising in the first place and $b$ ) the danger of moral hazard, once there, affecting them negatively. The insurance industry offers well known illustrations. In health insurance, for example, exclusions, deductibles and co-pays are tools intended to reduce moral

8) Expectations have very similar implications in a number of other cases which, although they seem to have affinities with cases of moral hazard, do not feature any moral hazard at all because there is no harm for third parties. Such cases are especially widespread in sports. For example, the introduction of mandatory helmets in professional ice hockey has made it possible for players to engage in more violent attacks without fearing pain and skull fractures. As a result, the sport has become more violent. But it has not produced expropriation. Nobody is forced to play in the American NHL and those who do play there know what they are heading for. Actually, there might be more than just a few players who enjoy the greater violence that is possible only with helmets. The same thing holds true for mandatory helmets and shoulder pads in American football, mandatory gloves in professional boxing, and similar cases.

In other cases things get a little bit more complicated. Consider that technological advance often induces increased risk taking with potential adverse effects for third parties. Road safety is a case in point. Larger roads will incite drivers to go at a higher speed, thus increasing the probability of road accidents. (The German autobahn system is a notorious example.) But the same effect-greater speed and thus greater numbers of victims - could be proven to result from virtually any technological progress that makes driving a car less risky, even from mandatory "safety belts." Every new technological advance that would make driving safer if the driver drove as before, actually creates an incentive for the driver to prop up his speed. Again, it does not follow that people who might be negatively affected should be considered as being expropriated. After all, nobody is forced to ride on a highway for which no speed control exists. And the reason why people do choose to use and finance such highways despite the known risks is that they benefit from the absence of speed limits even if they do not personally enjoy the thrills of high speed. For example, they might benefit, as consumers, from the lower transportation costs that result from higher speed; or, as patients, when they need a quick ride to the hospital or need urgent delivery of medication.

There is always a trade-off between desirable and undesirable consequences, which need to be properly balanced. The proper balance in turn will be different for different individuals. It will depend on individual values and thus will require individual choices. As long as all consequences of a decision fall on the decision-maker, economic analysis tells us that this individual will choose the balance that ranks highest on his value scale (ex ante). However, as soon as a choice concerns different individuals, we cannot infer, from the mere fact that the choice is ex ante optimal in the eyes of the decision-maker, that it is similarly optimal from a larger social point of view. Economic analysis is at a loss to compute the value judgements of different individuals (see Cuhel, 1907; Robbins, 1932; Rothbard, 1956). Such computations would require a common unit of value or utility, and no such unit is known to exist. By contrast, economic analysis can elucidate the causes and consequences of choice under different property regimes. The point of the present work is to show that the latter have indeed different tendencies to create moral hazard problems. 
hazard.$^{9)}$ Similarly, moral hazard in road traffic has been effectively reduced with the help of radar controls and black boxes in vehicles. ${ }^{10)}$

Most importantly, on a free market, principals have the liberty to sever contractual relations with agents at any time. The threat of being fired is probably the most powerful incentive to deliver diligent work rather than succumb to moral hazard (Mises, 1922). Reputation effects and blacklists operate in the same direction.

Analogous considerations apply to all forms of co-ownership. Here the various co-owners, being aware that the utilisation of the common resource must be restricted to preserve its value, have an incentive to set up and accept rules for its use. If the number of co-owners is high, individual capitalist-entrepreneurs might step in and provide the co-property and the rules. An important example is urban development (see MacCallum, 2003).

The institutional settings designed to neutralise moral hazard are usually considered to be "second-best" solutions, as distinct from the "first-best" solutions that would exist in a world inhabited with human beings that enjoy perfect information. Based on this distinction, some writers infer that competitive markets are inefficient in the presence of moral hazard (see for example Arnott and Stiglitz, 1985). In other words, moral hazard would be a systematic cause of market failures even on a free market.

However, the distinction between first-best and second-best solutions is a figment of the imagination. It is based on the premise that human beings could choose to inhabit a world in which they would be endowed with perfect foresight and in which they would not need any institutions designed to deal with moral hazard. Only in comparison to such an alternative world could the world that we know - the world with information asymmetries and moral hazard - be called inefficient. But the alternative does not exist. The only meaningful standard to evaluate the efficiency, say, of deductibles and co-pays are other contractual provisions or similar devices that could be used to attain the same end. Their efficiency cannot be gauged a priori (see Demsetz, 1969, who called this methodological error the "Nirvana fallacy").

\section{Moral Hazard and the Definition of Property Rights}

Before turning to the analysis of moral hazard under government interventionism, it might be useful to first consider the hybrid or intermediate case in which property rights are not clearly defined. The case is not only interesting from a systematic point of view, but also because, in practice, for a great number of economic goods there are no clearly defined property rights. Most notably we might think here of air and oceans and their inhabitants; birds and fish. Human beings appropriate these resources with only feeble attempts at creating something like property rights. Thus we have a system of co-ownership without rules. Not surprisingly, the result is something like a universal moral hazard; everybody has an incentive

9) On active and passive monitoring, see Jean Tirole (2001). On protective mechanisms against asymmetric information in the financial markets, see Bebczuk (2003). In his study of moral hazard in insider trading, Alexandre Padilla (2002) discusses the following institutions through which moral-hazard problems are minimised: contract law, (hostile) takeovers, internal and external managerial competition, reputation, blacklist, and boycott. He argues that insider trading due to agency problems tends to be minimised on the free market, whereas government interventionism tends to exacerbate these problems, because it weakens the principal's ability to govern their firms (for example, by threatening to end a labour contract) and actually encourages discretionary behaviour of the agents.

10) Insurers too use price discrimination and technological devices such as black boxes to incite "good risks" to show themselves. 
to use the resource in question as much as possible. This is a sure recipe for quick depletion, as has been known at least from the times of Aristotle. In more recent years, the phenomenon has been called "tragedy of the commons."11)

Now, in this practically highly important case, information asymmetries play no role whatever. Moral hazard would be at work here even if each co-owner were perfectly aware of the activities of his fellow-owners. We could even say that moral hazard would be here at work especially in the case in which every co-owner was perfectly aware of the activities of his fellow-owners.

\section{Interventionism and Moral Hazard}

Important though moral hazard stemming from a deficient or lacking definition of property rights might be in practice, it is no match for moral hazard that results from a forced separation of ownership and control. To this type of moral hazard we turn now.

By a "forced" separation of ownership and control we mean a separation brought about against the will of its owner. Although owners might be forced both by governments and by private parties, government interventionism is far more important in practice. This is so not only because of the greater quantitative impact, but also because, in our western societies at least, interventionism is usually enshrined in the law and thus can be anticipated.

Let us first stress that government interventionism must not be confused with a mixed economy. In the latter the government is one of several owners and it controls only its own property. By contrast, an interventionist government commands other property owners to use their resources in a different way than these owners themselves would have used them. ${ }^{12)}$ In so doing, the interventionist government makes some person or group $A$ (for example itself) the uninvited co-owner of other agent B's property. The essence of interventionism is precisely this: institutionalised uninvited co-ownership.

Government makes itself the uninvited and unwanted co-owner whenever it taxes, regulates, and prohibits. ${ }^{13)}$ The specific forms of taxation, regulation, and prohibition are myriad. The important fact is that any form of government interventionism, by its very nature, entails a forced separation of ownership and effective control.

Taxation means that the government proclaims itself the owner of (a certain share of) resources belonging to its subjects; and that it forces them to eventually hand over these resources, which the latter would not have yielded voluntarily (otherwise one would not speak of taxation, but of donations to the government). Today taxation does not concern concrete physical items, but their monetary equivalent. It follows that, until the tax is paid, the government imposes itself as the co-owner of virtually all physical assets of the taxpayers. However, until the tax is paid, the resources in question are typically controlled by the citizen.

Regulation means that the government proscribes a certain use of certain resources. This use is typically not the one that the citizens would have chosen (ot-

11) See Aristotle (350 B.C.E) in Politics, 1261b, said: "What is common to the greatest number gets the least amount of care." See also Mises (1940) in Nationalökonomie, idem, Human Action (1998). The term "tragedy of the commons" was coined by bioethicist Garret James Hardin (1968).

12) See Mises (1929: chap. 1). It goes without saying that all modern states are interventionist states.

13) We do not here consider the moral dimension of interventionism. In observing that the government makes itself the co-owner of property belonging to its subjects, we make a purely factual statement. It is safe to say that, subjectively, the government considers itself to be the co-owner of that property. Objectively, it has the power to impose its point of view (within the limits of economic law). 
herwise the regulation would be pointless). Again, the government thereby proclaims itself the co-owner of these resources. Consider the case price controls. If the government fixes a minimum wage rate, it effectively proclaims itself the co-owner of workers, because it does not allow them to work under conditions they see fit. And it also proclaims itself the co-owner of the capitalists or, more precisely, of the money that the latter plan to spend on labour. However, the government does not permanently control the actions of the workers, and it does not interfere with other uses of the capitalists' money.

Prohibition means that the government outlaws a certain use of certain resources altogether. Again, it thereby proclaims itself the co-owner of all resources that could be put to the prohibited use. For example, if it prohibits the production and sale of alcoholic beverages it effectively imposes itself as a co-owner of all resources that could be used for the production and sale of such drinks. However, it does not interfere when those resources are used in other employments.

Interventionism does not abolish private property. The citizens still have ownership and control of their property, even though they have to share both ownership and control with the government and its agents. ${ }^{14)}$ It is true that this forced co-ownership is usually a matter of degree. Increased interventionism increases. the share of government control of resources, though without outlawing other people's simultaneous control of these same resources. But the forced nature of the co-ownership itself is not a matter of degree. It is a categorical and essential feature of any intervention, be it ever so small.

Government interventionism always and everywhere entails a forced separation of ownership and control. It follows that, by its very nature, it creates a moral hazard both for the citizens and for the government. Most importantly, it creates a situation in which each of the parties involved (the citizens on the one hand and the government on the other hand) desires to expropriate the resources subject to interventionism at the expense of the other parties.

First consider the reaction of the citizens to taxation, regulation, and prohibition. From the very fact that intervention entails forced co-ownership it follows that the citizens have an incentive to evade the intervention. They can to some extend evade it because they have some control of their property. To avoid taxation, for example, they can choose to invest capital in a country with low taxes rather than in a country with high taxes; they can choose to emigrate to low-tax countries rather than stay in high-tax places; they can choose a profession that is less taxed than other professions; and they can choose to make fraudulent declarations of their income and capital. To evade regulations, they can choose not to buy or sell commodities subject to price controls, or they can choose to buy and sell them on the black market. To evade prohibitions, they can buy and sell prohibited items on the black market. However, operating on the black market is risky and thus very costly, and evasion to other countries is costly too. Thus it follows that there is an incentive for the citizens to use a greater part of their property for personal consumption rather than invest it. Hence, the general tendency of interventionism on the citizens is to entail excessive consumption and to make production more costly because of the necessity to evade the intervention.

But moral hazard also comes into play on the side of the government itself. Governments rely on the resource use that comes through taxation and regulation.

14) One could also argue the other way round: Interventionism is based on the premise that, in principle at least, the government owns all resources within society (because the government itself decides which resources it may control). Yet interventionism does not go the full way to total planning and total control; it leaves some margin of control to individual citizens. 
They will therefore tend to tax more and regulate more in order to neutralise the ways in which the citizens evaded its previous intervention. It will seek to "close the loopholes." We have here a basic mechanism of the dynamics of government interventionism. Interventionist governments have an incentive to extend taxation to all branches of economic life; to regulate industries that have so far escaped regulation; and to beat into submission the countries that serve as tax havens. The ultimate result is to reinforce the tendencies that we characterised above: excessive consumption and lacking production; in short, a general impoverishment of society.

It can hardly be over-emphasised that it is not co-ownership per se that causes these excesses. They are caused by the uninvited and unwanted co-ownership that springs from interventionism.

Notice that our foregoing analysis in no way depends on the existence of asymmetrical information. We can assume for the sake of argument that all citizens are perfectly aware of the government's activities, and that the government is also perfectly well informed about the activities of all citizens. All of this would not alter the picture. Government interventionism entails moral hazard both on the side of the government and on the side of the citizens. And this moral hazard cannot be neutralised by choosing appropriate contractual devices, because it has no contractual basis at all, but is imposed. It cannot be sidestepped by choosing to avoid the moral hazard-prone situation altogether, because the situation itself is imposed. The very meaning of interventionism is, as we have said, to overrule the choices of property owners.

And similarly, the workings of moral hazard cannot be eliminated or diminished by correct expectations, as in the case of moral hazard on the free market. The case is exactly the reverse. It is precisely when the citizens anticipate how high the next tax will be, and when it will hit them, that a moral hazard will start bearing on them and incite them to evade the tax.

\section{Fiat Money, Moral Hazard, and Disequilibrium}

Let us now turn to the discussion of an important case in which government interventionism produces moral hazard on a large scale: monetary interventionism.

The fundamental intervention, on which all other interventions in this field are built, is the imposition of a legal tender (see Hülsmann, 2004). The latter is a means of payment that the market participants are obliged to accept, even if they made contracts that stipulated payments in terms of other media of exchange. This intervention creates a moral hazard for the market participants to hoard or export the media of exchange that in their eyes are better than the legal tender, but which they are legally bound to use at par with the legal tender. The paradoxical result is that only the legal tender - the medium of exchange that everybody seeks to avoid - remains in circulation. The attempted evasion of the legal tender produces the opposite result. Economists call this phenomenon "Gresham's Law."

All contemporary paper-money systems are based on such legal tender privileges. Paper money does not compete with other monetary products on the free market, but is imposed by special privilege. It is therefore called fiat paper money. This institution is of great interest from the point of view of the theory of moral hazard. In fact it entails moral hazard on the greatest imaginable scale, again, both on the side of its producer and on the side of its users.

Fiat paper money creates moral hazard for the producer because he has the possibility to create ex nihilo virtually any amount of money and, thus, to buy virtually any amount of goods and services for sale. The only limit to this capacity is the hyperinflation that invariably results in the case of a great inflation of the money supply. 
But fiat paper money also creates moral hazard on the side of the money users - the citizens, the banks, and the governments - because they sooner or later come to realise that the masters of the printing press have the power to bail out virtually any bankrupt firm or government. Thus they engage in more or less reckless financial planning, expecting that the monetary authorities will not allow a great mass of reckless planners go bankrupt. This speculation has been borne out by the last thirty years. Public and private debts are at record heights all over the world.

Monetary theorists have been aware of this danger early on, even though they did not use the word "moral hazard" in this context. Here we should mention in the first place defenders of competitive money, such as Ludwig von Mises, F. A. Hayek, Murray Rothbard, and many other economists of the Austrian School. But neither has the problem escaped the attention of the champions of fiat money. Thus Walter Bagehot (1873), who coined the "lender of last resort" concept, warned that the central bank, while freely lending in times of financial duress, would have to avoid at any cost the impression that it would bail out the market participants. Some sixty years later, Herbert Simon (1936) stressed the need for rules rather than discretion in economic policy, essentially for the same reasons. And his disciple Milton Friedman $(1959,1969)$ reiterated this point even more famously in his proposal for a constant growth rate of the money supply.

The idea that rules could prevent large-scale moral hazard in a fiat paper money system defies human logic. After all, the only possible use of a printing press is to produce more money than would have been produced on a free market. What sense does it make to assert that this power could be handled responsibly? ${ }^{15)}$ In analogy to a felicitous phrase from Anthony de Jasay, we might say that praising the virtues of monetary stabilisation while maintaining legal tender laws for paper money is like using chastity belts for Miss World while handing over the keys to the lady. Let us add, though, that, to make the analogy with our monetary constitution perfect, we would have to advertise day in day out in the New York Times that Miss World definitely owns the key to her chastity belt. ${ }^{16)}$

Financial bubbles are the unavoidable result of such a state of affairs. If more or less every major participant to the financial market is subject to moral hazard then in due time even the smaller traders realise that the bigger fish play the moral hazard card, and thus they venture to set out on the same path. This means that the market participants sooner or later come to base their plans on the availability of a far greater quantity of goods and services than is really available in the economy. In short, paper money by virtue of its mere existence produces massive error on a large scale, until the bubble bursts in a crisis (see Hülsmann, 1998).

Again, as in the other cases of interventionism-induced moral hazard, these effects cannot be neutralised, avoided, or diminished through anticipations. And this means that they cannot be managed through the management of expectations. Kydland and Prescott (1977), along with the rest of the mainstream, have in the past thirty years laboured to bring expectations into the picture of monetary policy.

15) Some theoreticians point out that there are "gains from tying one's hands" in monetary policy. Self-imposed limitations of one's ability to expand the money supply (which could be institutionalised, for example, in the form of independent central banks or of currency boards) could yield the benefit of lower interest rates (see Gianeti and Pagano, 1988). This is true. But even the most stringent currency-board system makes for a relatively loose monetary policy - and, thus, relatively high interest rates - when compared to commodity money systems. And notice also that the "institutional safeguards" can usually be thrown over board with simple majorities.

16) In November 2003, the Federal Reserve System governor, Professor Bernanke gave a widely noticed address in which he stressed that, technically speaking, the central bank could print virtually any quantity of money and inject it into the economy. 
The next thirty years will presumably be needed to take account of institutionalised moral hazard. The problem is that our monetary system will not survive that long, if we can extrapolate the speed of the events of the past thirty years.

\section{Conclusion}

Conventional theory explains moral hazard as a consequence of information asymmetries. We have argued that information asymmetries are just one among several causes of moral hazard and that they entail negative consequences for third parties only accidentally. By contrast, moral hazard also results from government interventionism. And in this case negative consequences are systematic and do result even in the absence of information asymmetries.

The main practical implication of these findings is that the perennial presence of moral hazard is not so much as sign of market failure as it indicates government failure. The main theoretical implication of our work is that information asymmetries might not be the right place to look into when it comes to explaining pervasive disequilibria caused by moral hazard.

\section{References}

Arnott, R., Stiglitz, J. (1985), "Labor Turnover, Wage Structure, and Moral Hazard: The Inefficiency of Competitive Markets." Journal of Labor Economics, 3 (4), pp. 434-462.

Arrow, K. (1963), "Uncertainty and the Welfare Economics of Medical Care." American Economic Review, 53 (3), pp. 91-96.

(1985), "The Economics of Agency," in Pratt, J., Zeckhauser, R. eds., Principals and Agents: The Structure of Business. Boston: Harvard Business School Press, pp. 37-51.

Bagehot, W. (1873, 1962)," Lombard Street." Homewood, III.

Bebczuk, R. N. (2003), Asymmetric Information in Financial Markets. Cambridge: CUP.

Becker, G. (1983), "Theory of Competition among Pressure Groups for Political Influence." Quarterly Journal of Economics, 98 (3), pp. 371-400.

Becker, G., Ehrlich, I. (1972), "Market Insurance, Self Insurance and Self Protection." Journal of Political Economy, 80 (4), pp. 623-648.

Berle, A., Means, G. (1932), The Modern Corporation and Private Property. Chicago: Commerce Clearing House.

Čuhel, F. (1907), Die Lehre von den Bedürfnissen. Innsbruck: Wagner.

Demsetz, H. (1969), "Information and Efficiency: Another Viewpoint." Journal of Law and Economics, 12 (1), pp.

Dreher, A. (2004), "Does the IMF Cause Moral Hazard? A Critical Review of the Evidence" (Working Paper Universität Konstanz).

Friedman, M. (1959), A Program for Monetary Stability. New York: Fordham University Press. (1969), "The Optimal Quantity of Money." The Optimal Quantity of Money and other

Essays. Chicago: University of Chicago Press.

Gianetti, F., Pagano, M. (1988), "The Advantage of Tying One's Hands." European Economic Review, 32 (5), pp. 1055-1075.

Grossman, S., Hart, O. (1983), "An Analysis of the Principal-Agent Problem." Econometrica, 51, pp. 7-45.

Hardin, G. (1968), "The Tragedy of the Commons." Science," 162, pp. 1243-1248.

Hayek, F. A. (1945), "The Use of Knowledge in Society." American Economic Review, 35 (4), pp. $519-530$.

Hilferding, R. (1910, 1947), Das Finanzkapital. Berlin: Dietz.

Holmstrom, B. (1979), "Moral Hazard and Observability." Bell Journal of Economics, 10, pp. 74-91.

Hoppe, H. (1989), A Theory of Socialism and Capitalism. Boston: Kluwer. (1993), The Economics and Ethics of Private Property. Bosten: Kluwer. 
Hülsmann, J. G. (1998), Toward a General Theory of Error Cycles." Quarterly Journal of Austrian Economics, 1 (4), pp.

(2004), "Legal Tender Laws and Fractional-Reserve Banking." Journal of Libertarian Studies, 18(3), pp.

Katz, M., Rosen, H. (1994), Microeconomics. 2nd Ed. Irwin, III.: McGraw Hill.

Keynes, J. M. (1926), The End of Laissez-Faire. London: Hogarth Press.

Knight, F. H. (1921, 1971), Risk, Uncertainty, and Profit. Chicago: University of Chicago Press.

Kotowitz, Y. (1987), "Moral Hazard," in Eatwell, J. et al. eds., The New Palgrave. London: Macmillan, pp. 549-551.

Kydland, F., Prescott, E. (1977), "Rules Rather than Discretion: The Inconsistency of Optimal Plans." Journal of Political Economy, 85, pp. 473-491.

Laffont, J. J. (2002), Incentives and Political Economy. Oxford: Oxford University Press.

Laffont, J. J., Martimont, D. (2002), The Theory of Incentives: The Principal-Agent Model. Princeton: Princeton University Press.

MacCallum, S. H. (2003), "The Enterprise of Community: Market Competition, Land, and Environment." Journal of Libertarian Studies, 17 (4), pp. 1-15.

McTaggart, D., Findlay, C., Parkin, M. (1992), Economics. Sydney: Addison-Wesley.

Mirrlees, J. (1971), "An Exploration in the Theory of Optimum Income Taxation." Review of Economic Studies, 38, pp. 175-208.

(1976), "The Optimal Structure of Incentives and Authority within an Organisation."

Bell Journal of Economics, 7, pp. 105-131.

Mises, L. (1922, 1981), Socialism. Indianapolis: Liberty Fund.

(1928), Geldwertstabilisierung und Konjunkturpolitik. Jena: Fischer.

(1929), Kritik des Interventionismus. Jena: Fischer.

(1940), Nationalőkonomie. Geneva: Union.

$(1949,1998)$, Human Action. Auburn, Ala:Mises Institute.

Padilla, A. (2002), "Can Agency Theory Justify the Regulation of Insider Trading?" Quarterly Journal of Austrian Economics, 5 (1), pp. 3-38.

Robbins, L. (1932), The Nature and Significance of Economic Science. London: Macmillan.

Rothbard, M. N. (1956), "Toward a Reconstruction of Welfare and Utility Economics," in Sennholz, M. ed., On Freedom and Free Entreprise. Princeton: Van Nostrand. (1998), The Ethics of Liberty. 2nd Ed. New York: New York University Press.

Rothschild, M., Stiglitz, J. E. (1976), "Equilibrium in Competitive Insurance Markets: An Essay on the Economics of Imperfect Information." Quarterly Journal of Economics, 90, pp. 629-650.

Simon, H. G. (1936), "Rules Versus Authorities in Monetary Policy." Journal of Political Econo$m y, 44$, pp. 1-30.

Smith, V. (1936), The Rationale of Central Banking. London: King.

Spycher, S. (2000), Moral-Hazard-Verhalten der Arbeitnemer/innen in der Arbeitslosenversicherung. Empirische Untersuchung mit den Daten der Schweizerischen Arbeitskräfteerhebung 1991 bis 1999. Gutachten im Auftrag des Staatssekretariats für Wirtschaft und Arbeit.

Tirole, J. (2001), "Corporate Governance," Econometrica, 69, pp. 1-35. 


\title{
THE POLITICAL ECONOMY OF MORAL HAZARD
}

Jörg Guido HÜLSMANN, Faculté de Droit, d'Economie et de Gestion, Université d'Angers, France (e-mail: Guido.Hulsmann@univ-angers.fr).

\begin{abstract}
:
Conventional theory explains moral hazard as a consequence of information asymmetries. The present paper proposes an alternative approach. We argue that information asymmetries are just one among several causes of moral hazard and that they entail negative consequences for third parties only accidentally. By contrast, moral hazard also results from government interventionism. And in this case negative consequences are systematic and do result even in the absence of information asymmetries.
\end{abstract}

Keywords: Moral hazard, political economy, information asymmetries, economic systems, Austrian economics

JEL Classification: D00, D80, K00, P00 